MAXillo faCial AND PLASTIC SURGery

\title{
Is it possible to define the ideal lips?
}

\section{È possibile definire le labbra ideali?}

\author{
M. KAR ${ }^{1}$, N.B. MULUK², S.A. BAFAQEEH ${ }^{3}$, C. CINGI ${ }^{4}$ \\ ${ }^{1}$ Kumluca State Hospital, ENT Clinics, Antalya, Turkey; ${ }^{2}$ Kırlkkale University, Faculty of Medicine, ENT Department, \\ Kırıkkale, Turkey; ${ }^{3}$ King Saud University, Faculty of Medicine, ENT Department, Riyad-Saudi Arabia; ${ }^{4}$ Eskisehir \\ Osmangazi University, Faculty of Medicine, ENT Department, Eskisehir, Turkey
}

\section{SUMMARY}

The lips are an essential component of the symmetry and aesthetics of the face. Cosmetic surgery to modify the lips has recently gained in popularity, but the results are in some cases disasterous. In this review, we describe the features of the ideal lips for an individual's face. The features of the ideal lips with respect to facial anatomy, important anatomical landmarks of the face, the facial proportions of the lips and ethnic and sexual differences are described. The projection and relative sizes of the upper and lower lips are as significant to lip aesthetics as the proportion of the lips to the rest of the facial structure. Robust, pouty lips are considered to be sexually attractive by both males and females. Horizontal thirds and the golden ratio describe the proportions that contribute to the beauty and attractiveness of the lips. In young Caucasians, the ideal ratio of the vertical height of the upper lip to that of the lower lip is $1: 1.6$. Blacks, genetically, have a greater lip volume. The shape and volume of a person's lips are of great importance in the perception of beauty by humans. The appearance of the lips in part determines the attractiveness of a person's face. In females, fuller lips in relation to facial width as well as greater vermilion height are considered to be attractive.

KEY WORDS: Lip • Ideal lip • Horizontal thirds • Golden ratio • da Vinci’s classic proportions

\section{RIASSUNTO}

Le labbra sono una componente essenziale per la simmetria e l'estetica del viso. La chirurgia estetica delle labbra ha recentemento ottenuto grande popolarità, tuttavia i risultati in alcuni casi sono disastrosi. In questo lavoro di revisione, noi descriviamo le caratteristiche delle labbra ideali, quindi vengono elencate le caratteristiche delle labbra ideali nel rispetto dell'anatomia del viso, i punti di riferimento anatomici del viso, le giuste proporzioni delle labbra e le differenze in base al sesso e all'etnia. Le proiezioni e le relative misure del labbro superiore e inferiore sono importanti non solo per l'estetica delle labbra in sé, ma anche per le proporzioni del viso. Le labbra carnose sono considerate sensuali sia dal genere maschile sia da quello femminile. Le linee orizzontali (con le quali si può dividere un volto) e la "golden ratio" descrivono le proporzioni che contribuiscono alla bellezza e all'attratività delle labbra. Nei giovani caucasici, il rapporto ideale tra l'altezza del labbro superiore e quella del labbro inferiore è di 1:1,6. Gli individui di razza nera hanno, geneticamente, delle labbra molto grandi. La forma e il volume delle labbra di una persona sono di notevole importanza per la percezione di bellezza da parte degli altri individui. Le labbra pertanto sono determinanti per l'attrattività di una persona. Nelle donne, le labbra carnose, in relazione alla larghezza del viso, così come l'altezza del vermiglio, sono considerate attraenti.

PAROLE CHIAVE: Labbra $\bullet$ Labbra ideali $\bullet$ Proprzioni orizzontali $\bullet$ Golden ratio $\bullet$ Proporzioni classihe di da Vinci

Acta Otorhinolaryngol Ital 2018;38:67-72

\section{Introduction}

Beauty is defined as "a state of harmony - a balance of facial proportions - a balanced relationship among skeletal structures, teeth, and soft tissue" ${ }^{1}$ or as the relative measure of balance and harmony ${ }^{2}$. Aesthetics is "the study of beauty and to a lesser extent, its opposite, the ugly" " ${ }^{3}$ The main factor defining an individual's attractiveness is his or her face ${ }^{4}$. An attractive appearance has a strong influence on that person's everyday life ${ }^{5}$. Beautiful people are con- sidered friendlier, more intelligent, more interesting and more socially competent ${ }^{6-9}$.

The lips are an essential component of the symmetry and aesthetics of the face (Fig. 1). Anthropometric studies have shown that wider and fuller lips in relation to facial width as well as greater vermilion height contribute to defining female attractiveness ${ }^{10}$. Gonzalez-Ulloa ${ }^{11}$ described the changes of the lip with aging, including a less exposed vermilion and a relative loss of vermilion bulk. 
The projection and relative sizes of the upper and lower lips are as significant to lip aesthetics as the proportion of the lips to the other facial structures. Additional important dimensions include the relative vertical length of the upper "red" lip to the length of the philtrum, or upper "white" lip. This is clearly demonstrated in the lips of the elderly, which are characterised by relative phitral excess and an atrophic upper red lip. On anterior view, the height of the upper red lip should be less than that of the lower red lip, and the upper lip should project approximately $2 \mathrm{~mm}$ over the lower lip on profile ${ }^{12}$.

In virtually all females since the beginning of recorded history, full lips have been associated with youth, beauty and voluptuousness. Robust, pouty lips are considered to be sexually attractive by both males and females ${ }^{13}$. Recently, cosmetic surgery to modify the lips has gained in popularity, with the goal of increasing facial attractiveness, but the results are in some cases disasterous. In this review, we consider the features of the ideal lips for an individual's face.

\section{Anatomy of the lips}

\section{Muscles of the lips}

The orbicularis oris acts as a sphincter around the mouth. Its fibers interlace with those of all the other facial muscles that act on the mouth. The buccal and marginal mandibular branches of the facial nerve provide the motor supply to the orbicularis oris, whose actions include pursing, dilation and closure of the lips ${ }^{14}$.

The depressor anguli oris arises from the periosteum of the mandible, along the oblique line lateral to the depressor labii inferioris. Its fibers converge on the modiolus, together with fibers of the orbicularis oris, risorius and, in some individuals, levator anguli oris muscles. The marginal mandibular branch of the facial nerve supplies the depressor anguli oris, which depresses the corners of the mouth on contraction ${ }^{14}$.

The depressor labii inferioris arises from the oblique line of the mandible in front of the mental foramen, where it is coverd by fibers of the depressor anguli oris. It passes upward and medially to insert into the skin and mucosa of the lower lip and into fibers of the orbicularis oris ${ }^{14}$.

The mentalis arises from the incisive fossa of the mandible and descends to insert into the dermis of the chin. Contraction elevates and protrudes the lower lip and creates the characteristic "peach-pit" dimpling of the skin over the chin. The motor supply arises from the marginal mandibular nerve ${ }^{14}$.

The levator labii lies deep to the orbicularis oculi at its origin from the maxilla, just above the infraorbital foramen.
It passes downward to insert into the upper lip and orbicularis oris. A smaller slip of medially located muscle, the levator labii superioris alaeque nasi, originates from the frontal process of the maxilla and inserts into the nasal cartilage and upper lip. Both of these muscles are supplied by branches of the zygomatic and buccal branches of the facial nerve. Their function is to elevate the upper lip ${ }^{14}$.

The levator anguli oris arises deeply from the canine fossa of the maxilla, below the infraorbital foramen, and inserts into the upper lip. It is innervated on its superficial aspect by the zygomatic and buccal branches of the facial nerve. This muscle elevates the corners of the mouth ${ }^{15}$.

The risorius is often underdeveloped. This muscle arises from a thickening of the platysma muscle over the lateral cheek, the parotidomasseteric fascia, or both. It inserts into the corners of the mouth and pulls them laterally ${ }^{14}$ (Fig. 2).

\section{Important anatomical landmarks of the lips}

The upper lip extends from the base of the nose superiorly to the nasolabial folds laterally and to the free edge of the vermilion border inferiorly. The lower lip extends from the superior free vermilion edge superiorly to the commissures laterally and to the mandible inferiorly. Around

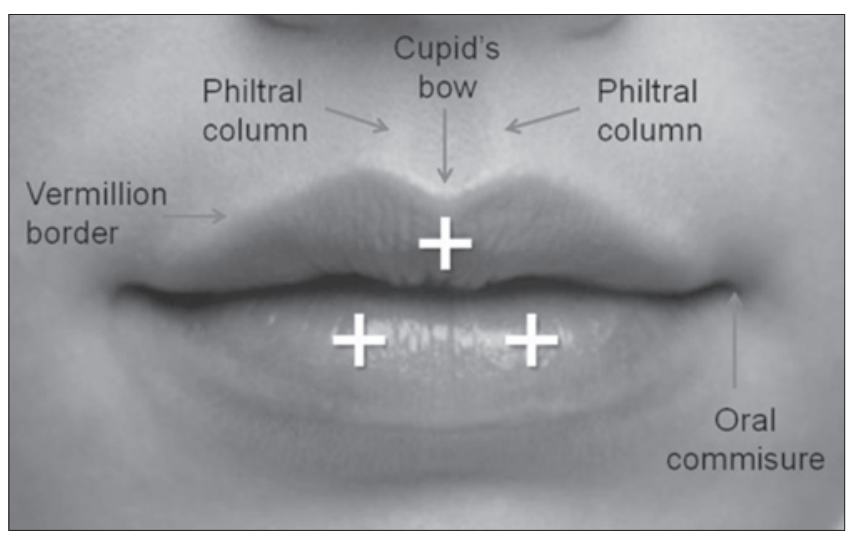

Fig. 1. The lips.

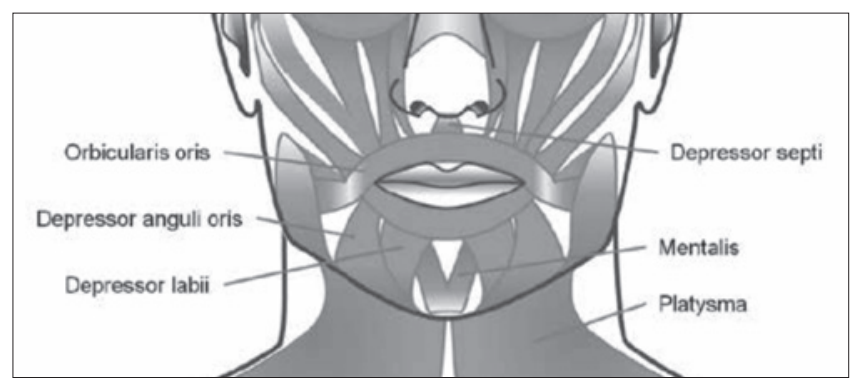

Fig. 2. Muscles of the lips (Adapted from Prendergast, $2013{ }^{14}$ ). 
the circumferential vermilion-skin border, a fine line of pale skin accentuates the colour difference between the vermilion and normal skin. Along the upper vermilionskin border, two paramedian elevations of the vermilion form Cupid's bow. Two raised vertical columns of tissue form a midline depression called the philtrum, which is located between the paramedian elevations of the vermilion and the columella above (Fig. 3). The labiomental crease passes horizontally in an inverted U-shape across the lower lip, which intraorally corresponds to the depth of the gingivolabial sulcus ${ }^{15}$.

\section{Facial proportions for the lips}

\section{Horizontal thirds}

The face is divided into horizontal thirds. The upper third extends from the hairline to the glabella, the middle third from the glabella to the subnasale and the lower third from the subnasale to the menton. These facial thirds are rarely equal in size. In Caucasians, the middle third is often smaller than the upper third and the middle and upper thirds are smaller than the lower third ${ }^{16}$. In East Asians, the middle third of the face is often larger than the upper third and equal to the lower third, and the upper third is smaller than the lower third ${ }^{17}$. The lower third is also divided into thirds; these define the upper lip, lower lip and chin (Fig. 4) ${ }^{18}$.

\section{The golden ratio}

Beauty and facial attractiveness are easily identified but difficult to quantify. Despite its subjective nature, we can attempt to define, measure and explain the captivating phenomenon of beauty by describing it numerically and geometrically ${ }^{19}$. The golden ratio, denoted by the symbol $\Phi$ (phi), is an irrational number of the order 1.618033988 . It is obtained when a line $a+b$ is sectioned such that $\mathrm{a}+\mathrm{b} / \mathrm{a}=\mathrm{a} / \mathrm{b}$ (Fig. 5) ${ }^{18}$. Although Indian mathematicians studied the golden ratio over 2,000 years ago, it first appeared in written documentation in Euclid's elements in $\sim 300$ B.C. ${ }^{20}$. The golden ratio, also known as the divine proportion, is considered by many to be the key to the mystery of aesthetics, attraction and human beauty ${ }^{21}$. The width of the mouth is $\Phi$ times the width of the nose. The distance between the lateral canthi is $\Phi$ times the width of the mouth. The height of the face from the pupils to the chin is $\Phi$ times the height from the hairline to the pupils. The volume and, therefore, the vertical height of the vermilion of the upper and lower lips should ideally fit within the golden ratio (divine proportion), that is, yielding the value of $\Phi, 1: 1.618$. This is first seen with da Vinci's classic proportions of the lips relative to the rest of the face.
These basic artistic principles, first practiced hundreds of years ago, still apply today ${ }^{13}$.

On frontal view, the ideal upper lip: lower lip ratio is 1:1.6. The vertical height of the upper lip should be less than that of the lower lip. Females will often request augmentation of the upper lip alone, without considering the balance between the upper and lower lips. Thus, it is incumbent upon the physician to educate the patient regarding the ideal ratio. "Sausage" or "duck" lips do not merely occur from overcorrection, but also from a poor understanding of the delicate contours of the normal lip anatomy. On lateral view, if a straight line is drawn from the subnasion to the pogonion, the upper lip should project $3.5 \mathrm{~mm}$ anterior to the line and the lower lip $2.2 \mathrm{~mm}$; the upper lip should project slightly more than the lower lip again about 1.6:1 (Fig. 6) ${ }^{13}$. An exaggeration of these proportions or the wrong ratio can lead to a "duck-like" or "trout-pout" appearance. Under no circumstances should the lips enter the room before the individual. The proportions of the lower thirds as applied by da Vinci further help to position the gnathion. A vertical reduction in chin height will help to achieve lip competence and correct the facial index. In contrast to the facial index, the lower third rules may be violated in females. The chin may be reduced more than indicated by the ideal proportion of $70 \%$ or even the $66 \%$ indicated by the classical canon ${ }^{22}$.

Marquardt devised a mathematical model that used $\Phi$ as the central measurement to map out facial proportions and aesthetically "ideal" shapes and sizes ${ }^{23}$. Despite general enthusiasm for the thesis that $\Phi$ is the Holy Grail in defining the beauty and harmony of the human form, Holland ${ }^{24}$ reminds us that several studies have not found a relationship between facial attractiveness and the golden ratio.

\section{Historical overview of beauty and facial proportions}

Long before scientists first attempted to appraise beauty, artists in the 4th century B.C. attempted to formulate rules for the ideally proportioned face. Greek artists were the first to execute their works according to these rules. For example, Aphrodite's head and body exhibit ideal proportions based on the concept of the golden section ${ }^{25}$, an allegedly ideal ratio between the lengths of two lines of $0.6180^{26}$.

The Romans later postulated their own rules, but following the Greek example. Thus, the Roman architect Vitruvius devised a famous threefold partition of the face, a concept adhered to even today in orthodontics and in oral and maxillofacial surgery During the Renaissance, renowned painters (da Vinci, Dürer, della Francesca) proposed rules for establishing ideal proportions to achieve optimum aesthetics and harmony. These rules, later adopted also by 


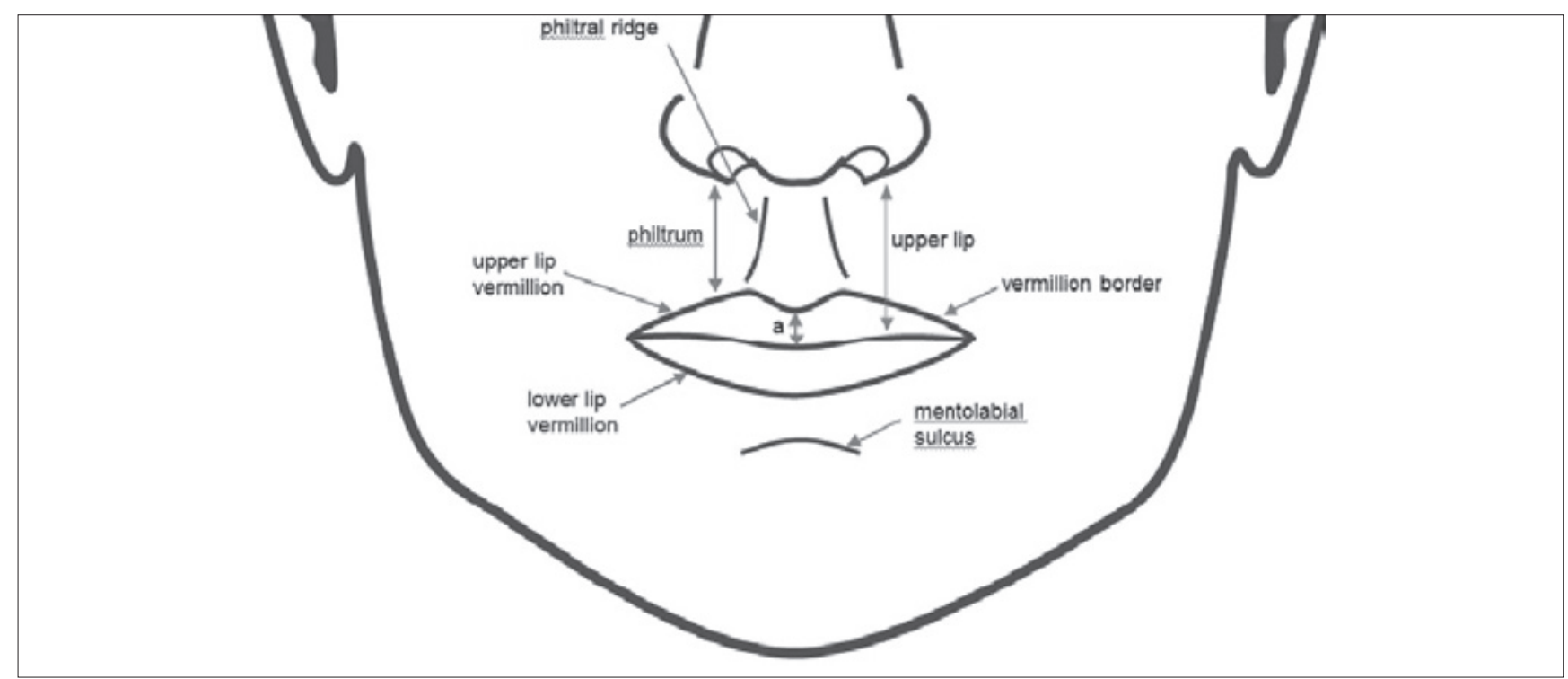

Fig. 3. Important anatomical landmarks of the lips.
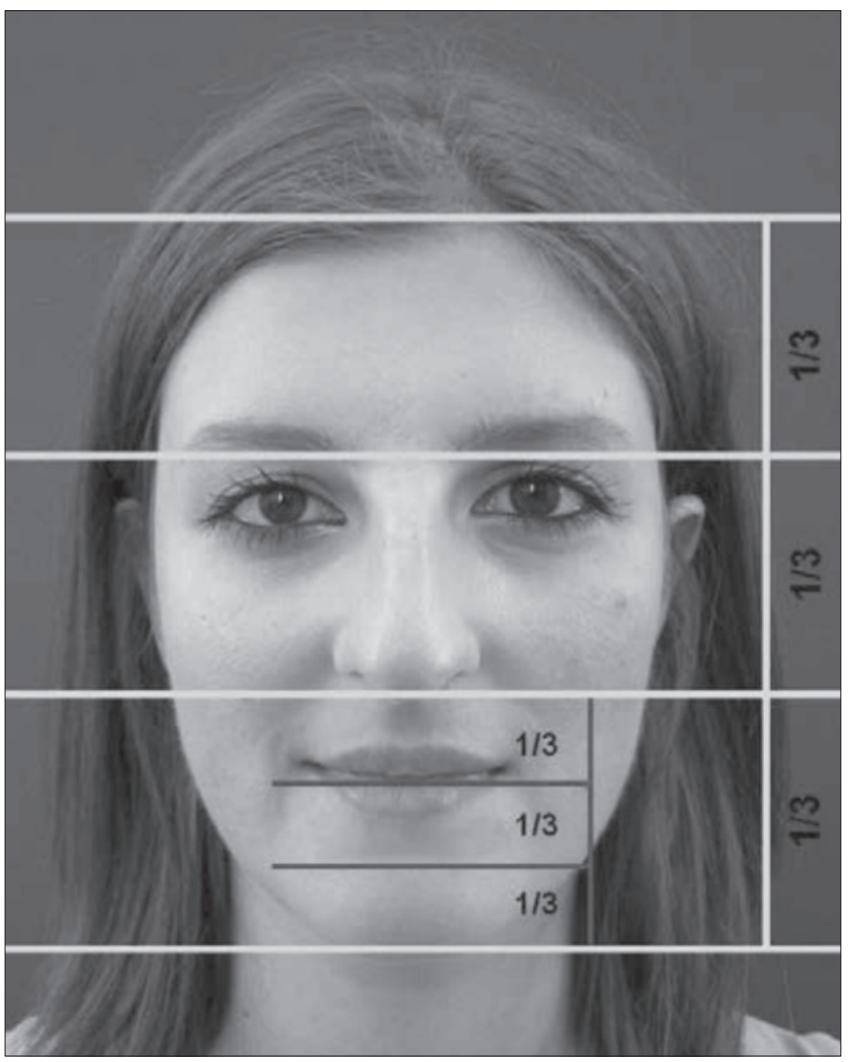

Fig. 4. Horizontal facial thirds. The upper third extends from the hairline to the glabella, the middle third from the glabella to the subnasale and the lower third from the subnasale to the menton. The lower third is also divided into thirds: the upper third extends from the subnasale to the stomion, the middle third from the stomion to the labiomental crease and the lower third from the labiomental crease to the menton. These thirds define the upper lip, lower lip and the chin (adapted from Prendergast, $2012{ }^{18}$ ). orthodontists and surgeons, were generally based on average values ${ }^{27}$.

\section{Ethnic differences in the lips}

In youthful Caucasians, the ideal ratio of the vertical height of the upper lip to that of the lower lip is $1: 1.6^{28}$. The fundamental proportions of the lips change as a person ages, with lengthening of the cutaneous portion of the upper lip and volume loss and thinning of the upper lip vermilion. Gravity, osteoporosis, dental changes, maxillomandibular bony resorption and further soft-tissue volume loss at the oral commissures cause the commissures to turn downward in a perpetual frown. While aging Caucasian males and females have similar hard and soft-tissue volume loss, with thinning of the vermilion and cutaneous portions of the lips, males generally do not develop rhytides of the upper and lower lips. This is because their skin is thicker, with more subcutaneous fat surrounding the terminal hair follicles (as opposed to the fine vellus hairs in females) ${ }^{13}$. Certain ethnic groups, especially Blacks, genetically have greater lip volume. Because the increased melanin in their skin is protective throughout their lifetimes, the skin of Blacks is less prone to solar elastosis. Consequently, they rarely develop radial rhytides in the lips and their vermilion tends to retain its volume even subsequent to aging ${ }^{13}$. Hwang $\mathrm{K}$ and Hwang SH reported that the ratio of vermilion size to mouth width was greater according to the Japanese than to the Korean ideals of beauty in the late $18^{\text {th }}$ and early $19^{\text {th }}$ centuries ${ }^{29}$. 


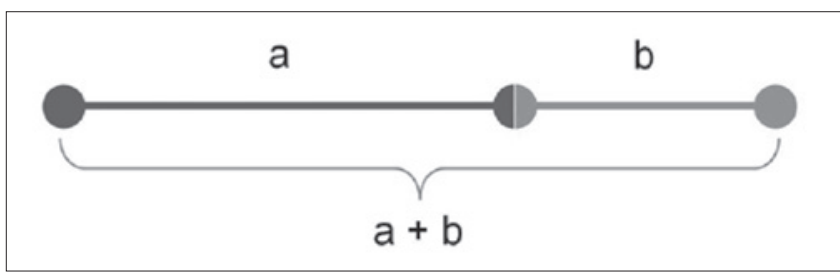

Fig. 5. The golden proportion. A line $(a+b)$ is sectioned such that $(a+b) / a=a / b=1.618033988^{*}$.

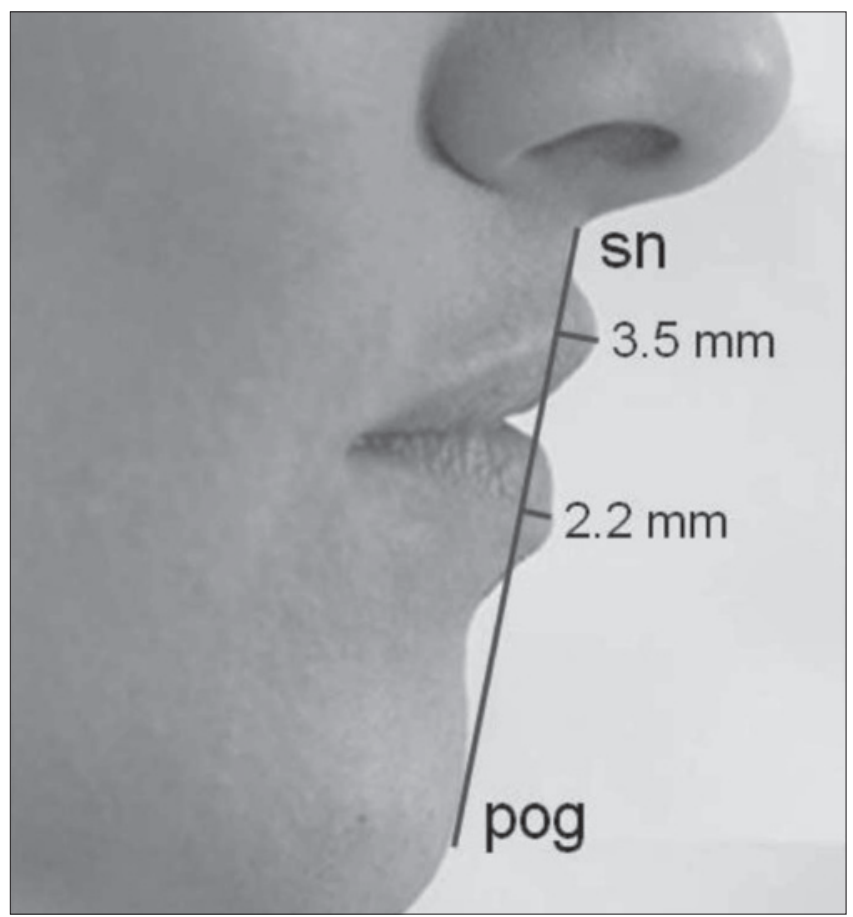

Fig. 6. In lateral view, an analysis according to the golden ratio.

\section{Gender differences in the lips}

Anic-Milosevic et al. ${ }^{30}$ compared the proportions of the lower facial third segments in males and females. The chin accounted for the largest segment and the lower lip height the smallest in both sexes. Although the vermilion heights of the upper and lower lips did not differ between males and females, upper and lower lip heights were larger in males. In both sexes, the height of the upper vermilion was smaller than that of the lower vermilion. The height of the vermilion of the upper lip relative to the upper lip itself was significantly greater in females than in males. The width of the lips should be about $40 \%$ of the width of the lower face and generally equal to the distance between the medial limbi. The width-to-height ratio of the face is typically $3: 4$, with an oval-shaped face being the aesthetic ideal.

Hier et al. ${ }^{31}$ reported that females prefer fuller lips to a greater degree than do males. Czarnecki et al. ${ }^{32}$ created androgy- nous facial silhouettes and asked 545 professionals to evaluate the profiles constructed with various lips, chin and nose relations. The authors found that a slightly convex profile was desirable for females and a straighter profile for males. The index of the lower facial thirds was unchanged for 2500 years, without differences between males and females. However, in the average contemporary ideal, the female face is shorter than the male face, although the interpupillary distances are similar. The harmonious male face is longer than its counterpart during antiquity. The ideal lower facial height in contemporary idealised females and males is $45 \%$ and $48 \%$ of the total facial height, respectively. During antiquity, it was $50 \%$ for both. The ideal ratio chin height/total lower facial height is $70 \%$ on average, with no differences between the sexes, whereas it was $66 \%$ in the classical canon. In the lower face, the Vitruvian thirds should be adjusted so as to yield a proportion corresponding to $30 \%$ upper lip and $70 \%$ lower lip-chin. The contemporary ideal ratios are suitable for use in orthofacial planning ${ }^{22}$.

According to Baudouin and Tiberghien ${ }^{33}$, full lips contribute to the attractiveness of a female face, together with large eyes, prominent cheekbones, thin eyebrows and a small nose and chin. The centre of the face thus consists of baby-like features, while the periphery implies sexual maturity. In the opinion of those authors, males find this type of female face particularly alluring.

Michiels and Sather ${ }^{34}$ attempted to describe the essentials of facial beauty in Caucasian females. They concluded that the chin, upper lip and nose were particularly important factors in the perception of attractiveness.

\section{Conclusions}

The lips are of great importance for the perception of beauty by humans. The appearance of the lips in part determines the attractiveness of a person's face. Fuller lips in relation to facial width and greater vermilion height are perceived as attractive in females. Horizontal thirds and the golden ratio provide the proportions for beauty and attractiveness, also of the lips. The golden ratio has been used since da Vinci's time and has been applied to describe the classic proportions of the lips relative to the rest of the face. In youthful Caucasians, the ideal ratio of the vertical height of the upper lip to that of the lower lip is 1:1.6. Blacks genetically have greater lip volume.

\section{Acknowledgements}

The authors extend their appreciation to the International Scientific Partnership Program ISPP at King Saud University for funding this research work through ISPP\# 0041. 


\section{References}

1 Dierkes JM. The beauty of the face: an orthodontic perspective. JADA 1987; Spec No:89E-95E.

2 Powell N, Humphreys B. Proportions of the aesthetic face. New York: Thieme-Stratton 1984.

3 Bell R, Kiyak HS, Joondeph DR, et al. Perceptions of facial profile and their influence on the decision to undergo orthognathic surgery. Am J Orthod Dentofacial Orthop 1985;88:323-32.

4 Mueser KT, Grau BW, Sussman S, et al. You are only as pretty as you feel: facial expression as a determinant of physical attractiveness. J Pers Soc Psychol 1984;46:469-78

5 Faure JC, Rieffe C, Maltha JC. The influence of different facial components on facial aesthetics. Eur J Orthod 2002;24:1-7.

6 Baldwin DC. Appearance and aesthetics in oral health. Community Dent Oral Epidemiol 1980;8:244-56.

7 Berscheid E. An overview of the psychological effects of physical attractiveness. In: Lucker G, RKMJ, editors. Psychological aspects of facial form. Michigan: University of Michigan Press; 1980. p. 1-25.

8 Cunningham MR, Barbee AP, Pike CL. What do women want? Facial metric assessment of multiple motives in the perception of male facial physical attractiveness. J Pers Soc Psychol 1990;59:61-72.

9 Lew KK. Attitudes and perceptions of adults towards orthodontic treatment in an Asian community. Community Dent Oral Epidemiol 1993;21:31-5.

10 Farkas LG, Kolar JC. Anthropometrics and art in the aesthetics of women's faces. Clin Plast Surg 1987;14599-616.

11 Gonzalez-Ulloa M. The aging upper lip. In: Marchac D, Hueston JT, editors.Transactions of the sixth international congress of plastic and reconstructive surgery. Paris: Masson; 1975. p. 443-446.

12 Jacono AA, Quatela VC. Quantitative analysis of lip appearance after V-Y lip augmentation. Arch Facial Plast Surg 2004;6:172-7.

13 Sarnoff DS, Gotkin RH. Six steps to the "perfect" lip. J Drugs Dermatol 2012;11:1081-8.

14 Prendergast PM. Anatomy of the Face and Neck. In: Shiffman MA, Di Giuseppe A, editors. Cosmetic surgery, arts and techniques. Springer 2013. DOI 10.1007/978-3-642-21837-8.

15 Jahan-Parwar B, Blackwell K. Lips and perioral region anatomy. Medscape. http://emedicine.medscape.com/article/835209overview (Received online at April, 13 ${ }^{\text {th }}, 2015$ ).

16 Farkas LG, Hreczko TA, Kolar JC, et al. Vertical and horizontal proportions of the face in young adult North American Caucasians: revision of neoclassical canons. Plast Reconstr Surg 1985;75:328-38.
17 Sim RST, Smith JD, Chan ASY. Comparison of the aesthetic facial proportions of Southern Chinese and white women. Arch Facial Plast Surg 2000;2:113-20.

18 Prendergast PM. Facial proportions. In: Erian A, Shiffman MA, editors. Advanced surgical and facial rejuvenation. Berlin Heidelberg: Springer-Verlag; 2012.

19 Atiyeh BS, Hayek SN. Numeric expression of aesthetics and beauty. Aesthet Plast Surg 2008;32:209-16.

20 Vegter F, Hage J. Clinical anthropometry and canons of the face in historical perspective. Plast Reconstr Surg 2000;106:1090-6.

21 Bashour M. History and current concepts in the analysis of facial attractiveness. Plast Reconstr Surg 2006;118:741-56.

22 Mommaerts MY, Moerenhout BA. Ideal proportions in full face front view, contemporary versus antique. J Craniomaxillofac Surg 2011;39:107-10.

23 Marquardt SR. Dr Stephen Marquardt and the golden decagon of human facial beauty. Interview with Dr Gottlieb. J Clin Orthod 2002;36:317-8.

24 Holland E. Marquardt's phi mask: pitfalls of relying on fashion models and the golden ratio to describe a beautiful face. Aesthet Plast Surg 2008;32:200-8.

25 Ricketts RM. The biologic significance of the divine proportion and Fibonacci series. Am J Orthod 1982;81:351-70.

26 Hönn M, Göz G. The ideal of facial beauty: a review. J Orofac Orthop 2007;68:6-16.

27 Edler RJ. Background considerations to facial aesthetics. J Orthod 2001;28:159-68.

28 Mandy S. Art of the lip. Dermatol Surg 2007;33:521-2.

29 Hwang K, Hwang SH. Anthropometric comparison of portraits of Korean and Japanese beauty in the late $18^{\text {th }}$ and early $19^{\text {th }}$ centuries. J Craniofac Surg 2005;16:790-3.

30 Anic-Milosevic A, Mestrovic S, Prlic A, et al. Proportions in the upper lip-lower lip-chin area of the lower face as determined by photogrammetric method. J Craniomaxillofac Surg 2010;38:90-5.

31 Hier LA, Evans CA, BeGole EA, et al. Comparison of preferences in lip position using computer animated imaging. Angle Orthod 1999;69:231-8.

32 Czarnecki ST, Nanda RS, Currier GF. Perceptions of a balanced facial profile. Am J Orthod Dentofacial Orthop 1993;104:180-7.

33 Baudouin JY, Tiberghien G. Symmetry, averageness, and feature size in the facial attractiveness of women. Acta Psychol [Amst] 2004;117:313-32

34 Michiels G, Sather AH. Validity and reliability of facial profile evaluation in vertical and horizontal dimensions from lateral cephalograms and lateral photographs. Int J Adult Orthodon Orthognath Surg 1994;9:43-54. 